\title{
Detection of Cell Mediated Immune Response in Chickens Immunized with Eimeria tenella Sporozoites
}

\author{
S. Saravanan*, K.M. Palanivel, T.J. Harikrishnan and G. Selvaraju
}

Department of Veterinary Preventive Medicine, Veterinary College and Research Institute, Tamil Nadu Veterinary Animal Sciences University, Namakkal-637 002, Tamil Nadu, India

*Corresponding author

\begin{tabular}{|c|c|}
\hline & A B S T R A C T \\
\hline $\begin{array}{l}\text { Broiler chickens, } \\
\text { E. tenella } \\
\text { sporozoites, ELISA, } \\
\text { CMI, Lesion score, } \\
\text { Bodyweight. }\end{array}$ & \multirow{3}{*}{$\begin{array}{l}\text { Purified E. tenella sporozoites were administered subcutaneously in neck region of } \\
\text { broiler chickens in different age groups and the cell mediated immune response in } \\
\text { terms of gamma interferons by ELISA was assessed. The mean IFN- } \gamma \text {. } \\
\text { concentration (pcg) in this experimental trial was significantly higher }(\mathrm{P}<0.01) \text { in } \\
\mathrm{T} 4(226.61 \pm 6.41) \text { and lower in T1 }(159.73 \pm 2.37) \text { than other groups. On } 49^{\text {th }} \text { day of } \\
\text { age, the concentration declined but higher in group T4 }(154.65 \pm 3.66) \text { than the } \\
\text { other groups. The mean weekly weight gain }(\mathrm{g}) \text { after challenge was high in T4 } \\
(2342.50 \pm 42.483) \text { with a low mean lesion score }(2.5 \pm 0.22) \text {. A partial protective } \\
\text { cellular immune response against caecal coccidiosis with a mean bodyweight gain } \\
\text { and mean lesion score superior to the unimmunized infected chickens could be } \\
\text { observed in this study. }\end{array}$} \\
\hline Article Info & \\
\hline $\begin{array}{l}\text { Accepted: } \\
\text { 17 April } 2017 \\
\text { Available Online: } \\
10 \text { May } 2017\end{array}$ & \\
\hline
\end{tabular}

\section{Introduction}

The Indian poultry sector has become a major contributor to the national economy as a result of the revolutionary and scientific approaches in avian health care management. Indian poultry industry contributes nearly Rs. 9.9 billion annually to the national economy (Mohana Subramanian et al., 2010). In India, broiler chicks are reared in deep litter system under farm condition which leads to frequent occurrence of the disease and face maximum economic loss due to reduced body weight gain, followed by increased feed conversion ratio $(23.74 \%)$ and chemoprophylaxis (2.83\%) due to coccidiosis (Bera et al., 2010), and the annual losses due to coccidiosis burden was estimated to be more than $\$ 800$ million worldwide (Kitandu and Juranova, 2006). Coccidiosis has long been known as important in poultry, and even today, control requires significant financial expenditure (Chapman, 2003).

Chickens are susceptible to at least 9 species of coccidia and the most common species is E. tenella, which causes caecal coccidiosis, while E. acervulina and E. maxima, cause chronic intestinal coccidiosis (Chandrakesan et al., 2009). Caecal coccidiosis is most frequent in young birds, especially at the age of four weeks (Soulsby, 1982). Currently, the increasing incidence of drug resistance to field strains of coccidian and residual effects 
in the poultry meat or eggs, poses a serious problem for producers (Peek and Landman, 2011). Obviously an alternative system to control coccidiosis is by vaccination, however, use of sporulated oocysts as live vaccines has limited application (Vermeulen et al., 2001) necessitating alternate immunological approaches to control the disease.

In this context, this paper presents the assessment of potency of the E. tenella sporozoites administered by parenteral route in broiler chickens, by enzyme linked immunosorbent assay (ELISA) by detecting cell mediated immune response and the efficacy in terms of bodyweight and lesion score in immunized broilers.

\section{Materials and Methods}

In this experimental trial, five groups of day old Cobb 400 broiler chicks were used $(n=15)$ and purified sporozoite antigen was administered subcutaneously @ $0.1 \mathrm{ml}$ per bird in the neck region, to groups $\mathrm{T} 1$ to $\mathrm{T} 4$ and T5 was kept as control. Groups, T1 and $\mathrm{T} 2$ were administered 10 and $20 \mu \mathrm{g}$ of live sporozoite antigen, respectively on $2^{\text {nd }}$ day of age, and T3 and T4 were administered 10 and $20 \mu \mathrm{g}$ of live sporozoite antigen, respectively on $6^{\text {th }}$ day of age by subcutaneous route in the neck region. The project proposal of this research programme to conduct these studies was duly approved by Institutional Animal Ethics Committee (IAEC) of Veterinary College and Research Institute, Namakkal.

The sera collected from experimental trial were subjected to ELISA specific to chicken gamma interferons (IFN- $\gamma$ ) for assessment of cell mediated immune response. The assay was carried out as per the standard protocol of the manufacturer (Cusa Biotech Ltd, China). The concentration of IFN- $\gamma$ in the samples is then determined by comparing the O.D. of the samples to the standard curve. The duplicate readings for each standard, control, and sample were averaged and subtracted from the average zero standard optical density. A standard curve was generated using the professional soft "Curve Exert 1.3" by reducing the data to generate a four parameter logistic (4-PL) curve-fit. The data were linearized by plotting the log of the IFN- $\gamma$ concentrations versus the log of the O.D. and the best fit line can be determined by regression analysis. The concentrations of the test samples were derived from the following equation, Rational Function: $\mathrm{y}=(\mathrm{a}+\mathrm{bx}) /$ $\left(1+c x+d x^{\wedge} 2\right)$.

Where, a,b,c and d from the co efficient data are variables which vary based on the fitness of standard curve derived from the test standards of each test. Statistical analysis was performed by randomized block design (Snedecor and Cochran) and analysis of variance (ANOVA) with SPSS statistical software (version 10.01). The results obtained in the experimental trial are shown in table 1 and figure 1 . The potency of the sporozoite vaccine in terms of cell mediated immune response and efficacy in terms of bodyweight and lesion score after challenge with 10, 000 live E. tenella oocysts at 49 days of age were assessed.

\section{Results and Discussion}

In the present study, the mean IFN- $\gamma$ concentration (pcg) was significantly $(\mathrm{P}<0.01)$ high in $\mathrm{T} 4(226.61 \pm 6.41)$ followed by T2 (218.78 \pm 5.91$), \mathrm{T} 3(165.5 \pm 5.55)$ and T1 (159.73 \pm 2.37$)$. High concentrations in $\mathrm{T} 2$ and T4 observed at 14 days of age started declining thereafter. T1 and T3 showed high concentration at 7 days of age but started declining thereafter and this early decline might be due to the low antigenic dose in the vaccine when compared to T2 and T4. 
Table.1 Assessment of cell mediated immune response by IFN- $\gamma$ based ELISA

\begin{tabular}{|c|c|c|c|c|c|c|c|}
\hline \multirow{2}{*}{ 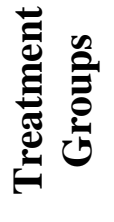 } & \multicolumn{7}{|c|}{ Gamma interferon concentration in Pcg (Mean \pm SE) } \\
\hline & $7^{\text {th }}$ day & $14^{\text {th }}$ day & $21^{\text {st }}$ day & $28^{\text {th }}$ day & $35^{\text {th }}$ day & $42^{\text {nd }}$ day & $49^{\text {th }}$ day \\
\hline T1 & $159.73^{\mathrm{BT}} \pm 2.37$ & $117.08^{\mathrm{BR}} \pm 4.56$ & $142.92^{\mathrm{CS}} \pm 3.66$ & $155.79^{\mathrm{CDT}} \pm 4.26$ & $82.51^{\mathrm{BQ}} \pm 3.8$ & $54.58^{\mathrm{BP}} \pm 3.23$ & $62.76^{\mathrm{BP}} \pm 2.52$ \\
\hline $\mathbf{T 2}$ & $204.57^{\mathrm{CST}} \pm 10.7$ & $218.78^{\mathrm{CT}} \pm 5.91$ & $171.81^{\mathrm{DQR}} \pm 5.12$ & $162.94^{\mathrm{CDQ}} \pm 6.00$ & $188.74^{\mathrm{DRS}} \pm 2.17$ & $156.82^{D_{ \pm}}+69$ & $91.41^{\mathrm{CP}} \pm 2.69$ \\
\hline T3 & $165.50^{\mathrm{BRS}} \pm 5.55$ & $120.51^{\mathrm{BR}} \pm 2.92$ & $108.41^{\mathrm{BRQ}} \pm 3.85$ & $119.91^{\mathrm{BR}} \pm 3.12$ & $75.51^{\mathrm{BP}} \pm 2.45$ & $93.39^{\mathrm{CQ}} \pm 4.06$ & $67.53^{\mathrm{BP}} \pm 5.25$ \\
\hline T4 & $192.75^{\mathrm{CRS}} \pm 3.12$ & $226.61^{\mathrm{CST}} \pm 6.41$ & $182.95^{\mathrm{DRS}} \pm 5.96$ & $134.59^{\mathrm{BCP}} \pm 2.90$ & $150.57^{C Q_{ \pm}} .61$ & $164.28^{\mathrm{DQ}_{ \pm 3} .65}$ & $154.65^{\mathrm{DQ}} \pm 3.66$ \\
\hline T5 & $10.39^{\mathrm{Apq}} \pm 1.01$ & $8.41^{\mathrm{Apq}} \pm 0.51$ & $10.33^{\mathrm{Apq}} \pm 0.31$ & $10.87^{\mathrm{Apq}} \pm 0.43$ & $10.87^{\mathrm{Apq}} \pm 0.61$ & $10.86^{\mathrm{Apq}} \pm 0.49$ & $12.33^{\mathrm{Aq}} \pm 0.54$ \\
\hline
\end{tabular}

**Row-wise mean $( \pm \mathrm{SE})$ with different superscript (pqr...) differ significantly $(\mathrm{P}<0.05)$, mean bearing 'upper case' superscript in a row are highly significant $(\mathrm{P}<0.01)$; *Column- wise mean $( \pm \mathrm{SE})$ with different superscript (abc...) differ significantly $(\mathrm{P}<0.05)$, mean bearing 'upper case' superscript in a column is highly significant $(\mathrm{P}<0.01)$.

Fig.1 Mean ELISA IFN- $\gamma$ levels in chickens of experimental trial

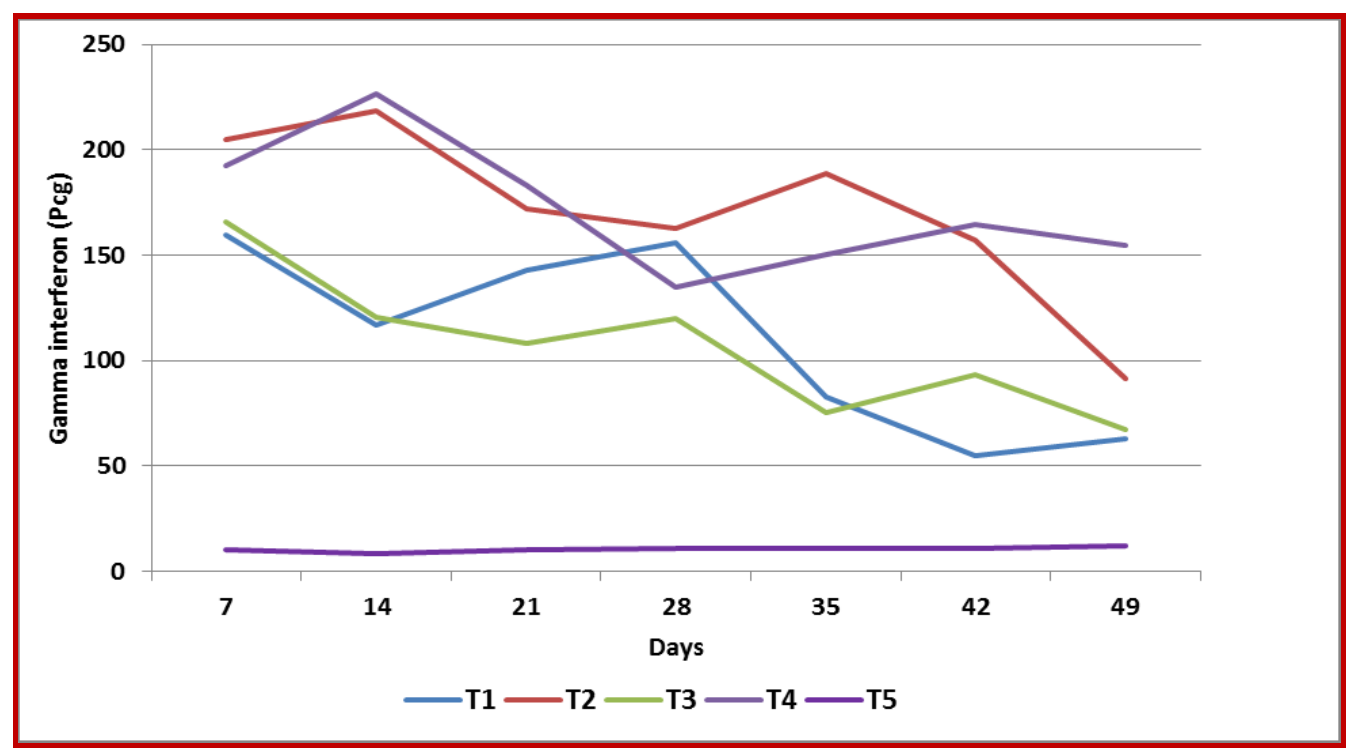


The mean IFN- $\gamma$ concentrations between weeks within each group were significantly different $(\mathrm{P}<0.01)$ when compared to control group. This finding is in concordance with that of Breed et al. (1999) and Prowse et al. (1991).

However, the IFN- $\gamma$ concentration (pcg) on day 49 was higher in T4 (154.65 \pm 3.66$)$, followed by T2 $(91.41 \pm 2.69), \quad \mathrm{T} 3$ $(67.53 \pm 5.25)$ and $\mathrm{T} 1(62.76 \pm 2.52)$ in this experimental trial. The mean IFN- $\gamma$ concentration in $\mathrm{T} 4$ and $\mathrm{T} 2$ were significantly high $(\mathrm{P}<0.01)$ than that of other vaccinated groups and this could probably be due to the higher antigenic dose administered to $\mathrm{T} 4$ and $\mathrm{T} 2$ than $\mathrm{T} 1$ and $\mathrm{T} 3$.

The mean weekly weight gain (g) after challenge, at 56 days of age was high in $\mathrm{T} 4$

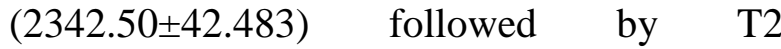

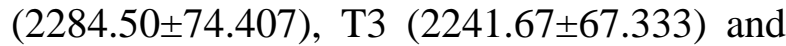
$\mathrm{T} 1(2214.67 \pm 40.426)$. The weight gains of all groups were found to be superior to that of unimmunized infected T5, however, inferior to that of unimmunized uninfected T5. Similar findings were recorded by Conway et al., (1990) and Kawazoe (2000). However, these weight gains were not significantly high $(\mathrm{P}>0.05)$ when compared to unimmunized infected T5 $(2278.20 \pm 85.418)$ but significantly $(\mathrm{P}<0.05)$ low when compared to unimmunized uninfected T5 (2518.83 \pm 38.704$)$. A low mean lesion score was observed in T4 $(2.5 \pm 0.22)$ followed by $\mathrm{T} 2 \quad(2.83 \pm 0.17), \mathrm{T} 1 \quad(3.33 \pm 0.33)$ and $\mathrm{T} 3$ (3.00 \pm 0.45$)$ in comparison with unimmunised infected T5 $(3.33 \pm 0.33)$ thus indicating a partial protection $(\mathrm{P}>0.05)$ by the sporozoites. A similar observation was recorded by Ziomko et al., (2005) and Geriletu et al., (2011). Interferons have been reported to be inimical to parasites, probably because of their ability to inhibit parasite development (Lillihoj and Choi, 1998), promote production of free radicals (Dimier and Bout, 1997) and activate antibody-dependent cell-mediated cytotoxicity (Fleischer, 1980).

Hence, it is concluded that immunization of broiler chickens of less than a week old by parenteral administration with $E$. tenella specific sporozoites could result in an early but partially protective cellular immune response against caecal coccidiosis with a mean bodyweight gain, and mean lesion score superior to the unimmunized infected chickens.

\section{Acknowledgement}

The authors are grateful to the TamilNadu Veterinary and Animal Sciences University, Chennai, TamilNadu, India for providing necessary financial assistance to carry out this research programme and the Dean of Veterinary College and Research Institute, Namakkal, TamilNadu, India for providing immense support and necessary facilities to carry out this research work.

\section{References}

Bera, A.K., D. Bhattacharyaa, D. Pana, A. Dharab, S. Kumarc and Das. S.K. 2010. Evaluation of economic losses due to coccidiosis in poultry industry in India. Agri. Economics Res. Rev., 23: 91-96.

Breed, D.G.J., T.P.M. Schetters, N.A.P. Verhoeven, A. Boot-Groenink, J. Dorrestein and Vermeule, A.N. 1999. Vaccination against Eimeria tenella infection using a fraction of E. tenella sporozoites selected by the capacity to activate T cells. Int. J. Parasitol., 29: 1231-1240.

Chapman, H.D. 2003. Origins of coccidiosis research in the fowl-the first fifty years. Avian Dis., 47: 1-20.

Chandrakesan, P., K. Muralidharan, V. Dinesh Kumar, G. Ponnudurai, T.J. Harikrishnan, K. Senthilvel and Rani, 
N. 2009. Efficacy of a herbal complex against caecal coccidiosis in broiler chickens. Veterinarski Arh., 79: 199203.

Conway, D.P., McKenzie, M., Elizabeth \& Dayton, A.D. 1990. Relationship of coccidial lesion scores and weight gain in infections of Eimeria acervulina, E. maxima and E. tenella in broilers. Avian Pathol., 19: 489 - 496.

Dimier, I.H., and Bout. D.T. 1997. Inhibition of Toxoplasma gondii replication in IFN activated human intestinal epithelial cells. Immunol. Cell Biol., 75: 511-514.

Fleischer, B. 1980. Effector cells in avian spontaneous and antibody-dependent cell-mediated cytotoxicity. J. Immunol., 125: 1161-1166.

Geriletu, B., L. Xua, Xurihuab and Li, X. 2011. Vaccination of chickens with DNA vaccine expressing Eimeria tenella MZ5-7 against coccidiosis. Vet. Parasitol., 177: 6-12.

Kawazoe, U. 2000. Coccidiose. In: A. Berchieri, M. Mcari, editors. Doenca das aves. Campinas: Facta, pp: 391405.

Kitandu, A. and Juranova, R. 2006. Review Article: Progress in Control Measures for Chicken Coccidiosis. Acta Veterinaria Brno, 75: 265-276.

Lillehoj, H.S. and Choi, K.D. 1998. Recombinant chicken interferongammamediated inhibition of Eimeria tenella development in vitro and reduction of oocyst production and body weight loss following Eimeria acervulina challenge infection. Avian Dis., 42: 307-314.

Mohana Subramanian, B., V. Lakshmipriya, A. Ramesh, T.J. Harikrishnan and Rajan, S. 2010. Sequence diversity of iternal transcribed spacer-1(ITS-1) region of Eimeria infecting chicken and its relevance in species identification from Indian field samples. Parasitol. Res., 106: 513-521.

Peek, H.W. and Landman, W.J.M. 2011. Coccidiosis in poultry: anticoccidial products, vaccines and other prevention strategies. Vet. Quarterly, 31: 143-161.

Prowse, S.J. 1991. Cell-mediated immunity to Eimeria in the fowl: The absence of cross-species protection is not due to the lack of cross-reactive $\mathrm{T}$ cells. Int $J$. Parasitol., 21:133-135.

Soulsby, E.J.L. 1982. In: Helminths, arthropods and protozoa of domesticated animals. Seventh Edition, Bailliere Tindall, London.

Vermeulen, A.N., D.C. Schaap, and Schetters, T.P.M. 2001. Control of coccidiosis in chickens by vaccination, Vet. Parasitol., 100: 13-20.

Ziomko, I., J. Karamon, T. Cencek, E. Gornowicz, A. Skoracki, and Ashash, U. 2005. Prevention of broiler chick coccidiosis using the inactivated subunit vaccine coxabic ${ }^{\circledR}$. Bull. Vet. Institute in Pulawy, 49: 299-302.

\section{How to cite this article:}

Saravanan, S., K.M. Palanivel, T.J. Harikrishnan and Selvaraju, G. 2017. Detection of Cell Mediated Immune Response in Chickens Immunized with Eimeria Tenella Sporozoites. Int.J.Curr.Microbiol.App.Sci. 6(5): 1513-1517. doi: https://doi.org/10.20546/ijcmas.2017.605.164 